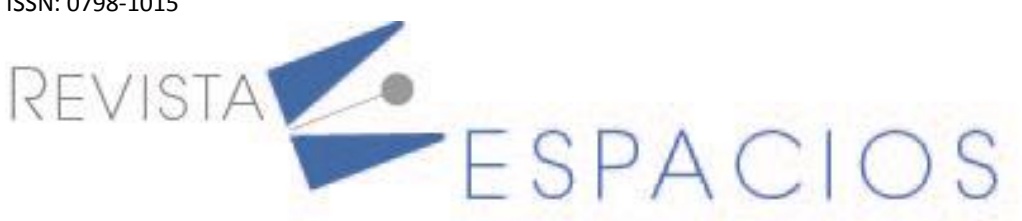

\title{
Analytical management tools of industrial systems strategic development
}

\section{Herramientas de gestión analítica del desarrollo estratégico de sistemas industriales}

\author{
SHAPRAN, Evgeniy M. ${ }^{1}$ \\ SERGIENKO, Olena A. ${ }^{2}$ \\ GAPONENKO, Olga E. ${ }^{3}$ \\ TATAR, Maryna S. ${ }^{4}$ \\ MOROZOVA, Nadiia L. ${ }^{5}$
}

\begin{abstract}
The paper studies analytical-applied and structural aspects of strategic management of industrial systems development on the bases of assessment and analysis of the potential of their development, the formation and implementation of strategic alternatives in the conditions of external and internal environmental threats. We propose to consider the analytical-applied and structural modeling tool as a set of scenario models for formation and implementation of business entities development strategies. Keywords: strategic development, models, threats, business entities, dymamics, scenarios
\end{abstract}

\begin{abstract}
Resumen
El trabajo estudia los aspectos analítico-aplicados y estructurales de la gestión estratégica del desarrollo de sistemas industriales sobre la base de la evaluación y análisis del potencial de su desarrollo, la formación e implementación de alternativas estratégicas en las condiciones de amenazas ambientales externas e internas. Proponemos considerar la herramienta de modelización analítico-aplicada y estructural como un conjunto de modelos de escenarios para la formación e implementación de estrategias de desarrollo de entidades empresariales.

Palabras clave: desarrollo estratégico, modelos, amenazas, entidades comerciales, dinámica, escenarios
\end{abstract}

\section{Introduction}

The distinctive feature of the modern stage of development of different levels systems is the process of allencompassing globalization, which gradually erases the regional and national borders, forming single integrated market space, characterized by the presence of co-evolutionary effects. Under these conditions, the development of open complex socio-economic systems, in particular enterprises, depends not so much on their

\footnotetext{
${ }^{1}$ Doctor of Technical Science, Professor. Department of Business, Trade and Products Expertise. National Technical University «Kharkiv polytechnic institute». Contact e-mail: evgen.shapran1948@gmail.com

2 PhD in Economics, Associate Professor. Department of Business, Trade and Products Expertise. National Technical University «Kharkiv Polytechnic Institute». Contact e-mail: serhelenka@gmail.com

${ }^{3} \mathrm{PhD}$ in Economics, Associate Professor. Department of Business, Trade and Products Expertise. National Technical University «Kharkiv Polytechnic Institute». Contact e-mail: gaponenko.oe@gmail.com

${ }^{4} \mathrm{PhD}$ in Economics, Associate Professor. Finance Department. National Aerospace University «Kharkiv Aviation Institute». Contact e-mail: marina.sergeevna.tatar@gmail.com

${ }^{5} \mathrm{PhD}$ in Economics, Associate Professor. Department of Management and Social Sciences and Humanities. Kharkiv Scientific Research Institute of the SHEI "Banking University”. Contact e-mail: morozova.nadiya@khibs.ubs.edu.ua
} 
internal real and potential opportunities, but on the influences and fluctuations of market environment, which, dynamically changing, serve as sources of variety of contradictions that determine the enterprise behavior in present and in future.

The conducted studies have shown that the activity of economic entities in the transformative conditions of Ukrainian economy is characterized by complex of contradictions, which include contradictions between management desire to manage the enterprise development on the basis of planned activity and incomplete determination of external and internal conditions; between diligence and creativity in employees activities; between the desire for stability enterprise development as a system and its variability; between the integrity of the enterprise and the freedom of its units; between the speed of change in external environment and speed of enterprise reaction to such changes, etc.

In the modern paradigm of management, industrial system in particular, industrial enterprise, is considered as an open system whose results is determined by its level of competitiveness, market position, ability to implement innovative projects, and personnel development level. Currently, enterprise management faces many challenges, the most difficult of which is the ability and possibility quickly and with minimal cost adapt to changes in the environment through the implementation of adequate development strategies. Consequently, the modern stage of management development is characterized by its orientation towards the awareness of the need to develop a modern model tool for strategic development of the enterprise, which ensures its adaptation to external and internal changes, taking into account the existing development potential.

These contradictions lead to the emergence of one of the most pressing problems of modern management - the problem of enterprise development management, the solution of which makes possible to ensure the strategic competitiveness of the enterprise and its adaptive diffusion into market environment, which is uncertain and stochastic, on the basis of establishing adequate target orientations of its effective development benchmarks influences on regulating the behavior of the enterprise over time.

The issue of industrial systems strategic development management improving is the subject of the study of many foreign and Ukrainian scholars: I. Ansoff, D. Aaker, St. Big, Kaplan R.S., G. Mintzberg, Pearce II J.A., Pogorelov Y.S., M. Porter, I. Prigogin, Robinson R.B., A. Thompson, J. Forester, J. Shumpeter, I. Blagun, V. Grineva, V. Zabrodsky, M. Kizim, T. Klebanova, R. Lepa, Y. Lysenko, V. Ponomarenko, O. Pushkar, O. Raevneva, O. Tridid, O. Tishchenko, O. Chernyak, Z. Shershneva Z. E., Voronkova A. E. and many others.

Ansof (1970) comprehensively researched task of constructing a strategic management system, the result of which was to substantiate a number of different management models.

Thus, according to Ansof (1970) the model of strategic management through the strategic positions choice involves the analysis of enterprise prospects; identification of priorities and allocation resources between different perspective activities; assessment of possible enterprise diversification; forecasting of instability factors dynamics; planning new strategies that meet expected levels of environmental instability; predicting organizational changes and enterprise capabilities.

In Table 1 is presented conceptual approaches to enterprise development strategies formation in accordance with scientific schools which are highlighted by Mintzberg, Alstrand, Lampel (2000). 
Table 1

Conceptual approaches to the formation of enterprise development strategies

\begin{tabular}{|c|l|}
\hline $\begin{array}{c}\text { School of Strategies and } \\
\text { Representatives }\end{array}$ & \multicolumn{1}{c|}{ Development Strategy Approach } \\
\hline $\begin{array}{c}\text { School of Planning (I. } \\
\text { Ansof) }\end{array}$ & $\begin{array}{l}\text { Strategy is the result of controlled, conscious process of formal planning, broken down into } \\
\text { separate steps: setting goals, organization of external and internal audit, drawing up an } \\
\text { enterprise development plan. }\end{array}$ \\
\hline $\begin{array}{c}\text { School of positioning } \\
\text { (D. Shendel, C. Hatten, M. } \\
\text { Porter) }\end{array}$ & $\begin{array}{l}\text { Formation of company development strategy is analytical process that makes possible to choose } \\
\text { the right strategy to the given environmental conditions. It is assumed that the market structure } \\
\text { actively stimulates the emergence of this positioning strategy, which, in turn, actively affects the } \\
\text { organizational structure. }\end{array}$ \\
\hline $\begin{array}{c}\text { School of Entrepreneurship } \\
\text { (I. Schumpeter, A. Cole) }\end{array}$ & $\begin{array}{l}\text { The strategy exists in the mind of the leader in the form of perspectives, intuitive choice of the } \\
\text { movement direction and prediction of company future. Entrepreneurial strategy is characterized } \\
\text { by flexibility, development during implementation of the strategy. }\end{array}$ \\
\hline $\begin{array}{c}\text { School of Knowledge } \\
\text { (G. Simon, } \\
\text { D. March) }\end{array}$ & $\begin{array}{l}\text { Formation of the organization's development strategy is mental process. Development } \\
\text { prospects (concepts, maps, schemes, frames) prescribe methods for obtaining information from } \\
\text { external environment. The received information is an interpretation of the world that can be } \\
\text { modeled, structured and constructed. }\end{array}$ \\
$\begin{array}{c}\text { School of External } \\
\text { Environment }\end{array}$ & $\begin{array}{l}\text { Formation of company development strategy is reactive process. The external environment } \\
\text { manifests itself as a set of forces and is the main element that determines the process of creating } \\
\text { organizational strategy. Leadership is seen as a passive element of the strategic process, and its } \\
\text { task is identification external forces and ensure the company's adaptation through concessions, } \\
\text { compromise, evasion, open disobedience and manipulation. }\end{array}$ \\
\hline
\end{tabular}

lastremska, Strokovych, Dzenis, Shestakova and Uman (2019) consider investment and innovative development of industrial enterprises as the basis for the technological singularity.

Ivanov and Kapustnik (2015) pay attention to economic expertise of strategic decisions in the system of strategic management of enterprise development. Lepa, Okhten and Prokopenko (2016) paper is dedicated to management of industrial enterprises development in the context of neo-industrialization. Voronkova (2004) explores the processes of diagnostics and organization of strategic management of enterprise competitive potential.

Considering the problem of enterprises development management in more detail Anisimova, Balan (2011) propose a model of the process of formation and selection of enterprise development strategies, which contains a procedural invariant of strategic planning and partial models related to the need to build scenarios for the future, determine the potential and competitive position of individual strategic business units and the enterprise as a whole. The advantages of such model include the fact that it reflects the triple nature of development process, result and immanent property.

Pogorelov (2010) revealed the triple nature of enterprise development - immanent property, result and process. The proposed approach to enterprise development modeling is complex, according to which a single model contains several partial models that differ in content and purpose, but are closely related. They are not separated from each other, but are part of a single model of development.

Raevneva (2006) enterprise development management divided into three subsystems: the mechanism of management of development goals, the mechanism of diagnostics, decision-making mechanism. As in the previous approaches, the advantages can be attributed to the versatility of modeling, much attention in the choice of development strategies is paid not only to the aspects of enterprise internal state, but also to the conditions of external environment. The level of indicators of macro-environment and micro-environment is considered. The complexity of modeling and the process of implementing the proposed model in practice can be attributed to the disadvantages. 
However, in scientific papers, the issues related to the development of a set of methods and models of assessment and analysis of strategic development that does not meet the needs of enterprises that are fueled in a dynamic environment have not been properly reflected. So there is need to develop complex mathematical and economic models of strategic development of industrial and economic systems on the bases of evaluation and analysis of their internal and external potencial.

This paper aim is upgrading of analytical-applied and structural aspects of strategic management of industrial systems development on the bases of assessment and analysis of the potential of their development, the formation, and implementation of strategic alternatives in the conditions of external and internal environmental threats.To achieve the aim, the following tasks were set and solved:

- to develop model basis for estimating and analyzing the strategic development of industrial systems under threat conditions;

- to build models of formation of a representative information space of research;

- to develop models of diagnostics of enterprise financial and economic activity;

- to build models of unsteady dynamics and long-term interaction of the development of the enterprise with the scope of its activity;

- to develop scenario models of enterprise development (formation and selection of strategic alternatives) under conditions of external and internal threats.

The complex of analytical-applied and structural aspects of strategic development alternatives which are developed on the basis of factor analysis, robust estimation, taxonomy, inverse numbers, multidimensional analysis, neural network technologies, econometric and time-series approaches, scenario modeling, fuzzy logic makes possible to increase the reasonableness and quality of strategic decisions.

\section{Methodology}

The proposed complex of models of industrial systems strategic development are based on the concept of sustainability system and provides selection of alternatives of enterprise development in terms of threats and includes such blocks of models as assessment and analysis of the factor space; assessment and analysis of strategic development; modeling of enterprise strategic development. This complex of models is presented in Fig. 1.

One of the most important conceptual scheme block (Fig. 1) is Block 1, which involves the indicators system formation which fully determine the characteristics of the various enterprise spheres (production, finance, human resources). Choice and justification of indicators are made on the bases of the methods of factor analysis, robust assessment and taxonomy and inverse calculation method. The resulting system of indicators is initial information for the implementation of models of other blocks. The system of indicators of the enterprise effectiveness of studied areas is the basis for building models of research of the external and internal environment.

Block 2 of conceptual model involves the implementation of complex of models of evaluation and analysis of strategic development in comparative dynamic context of external and internal environment. The model diagnostic basis of financial and economic enterprises activities is proposed for investigation the factors and parameters of the environment which are defined by common characteristics for industrial systems. 
The third block (Block 3) of models of conceptual scheme of strategic development modeling provides complex of scenario models implementation of models of the formation and realization of development strategies on the basis of construction of management model of development level, models of enterprise development strategic alternatives formation in terms of threats and models of implementation of priority directions of development.

So the complex tools are based on the following methods and models: theory of the viability of systems for describing the system of management of enterprise strategic development; methods of cluster and discriminant analysis for construction of classes of financial situations, recognition and assessment of financial status;

neural network methods for forecasting of enterprises state probability; taxonomy method for construction of integral indicators of development level in the main enterprise activity spheres; panel data methods for construction of autoregressive econometric models of estimation and forecasting of investigated processes development dynamics; methods of vector-autoregressive analysis for investigation of non-stationary dynamics of enterprise development; methods of system dynamics for construction of simulation model of enterprise development scenarios realization; method of scenarios simulation for analysis of possible variants of development in the conditions of threats action and the best scenarios determination; fuzzy set theory for choosing strategic development alternatives.

Figure 1

Conceptual scheme of the complex interrelations of strategic development models

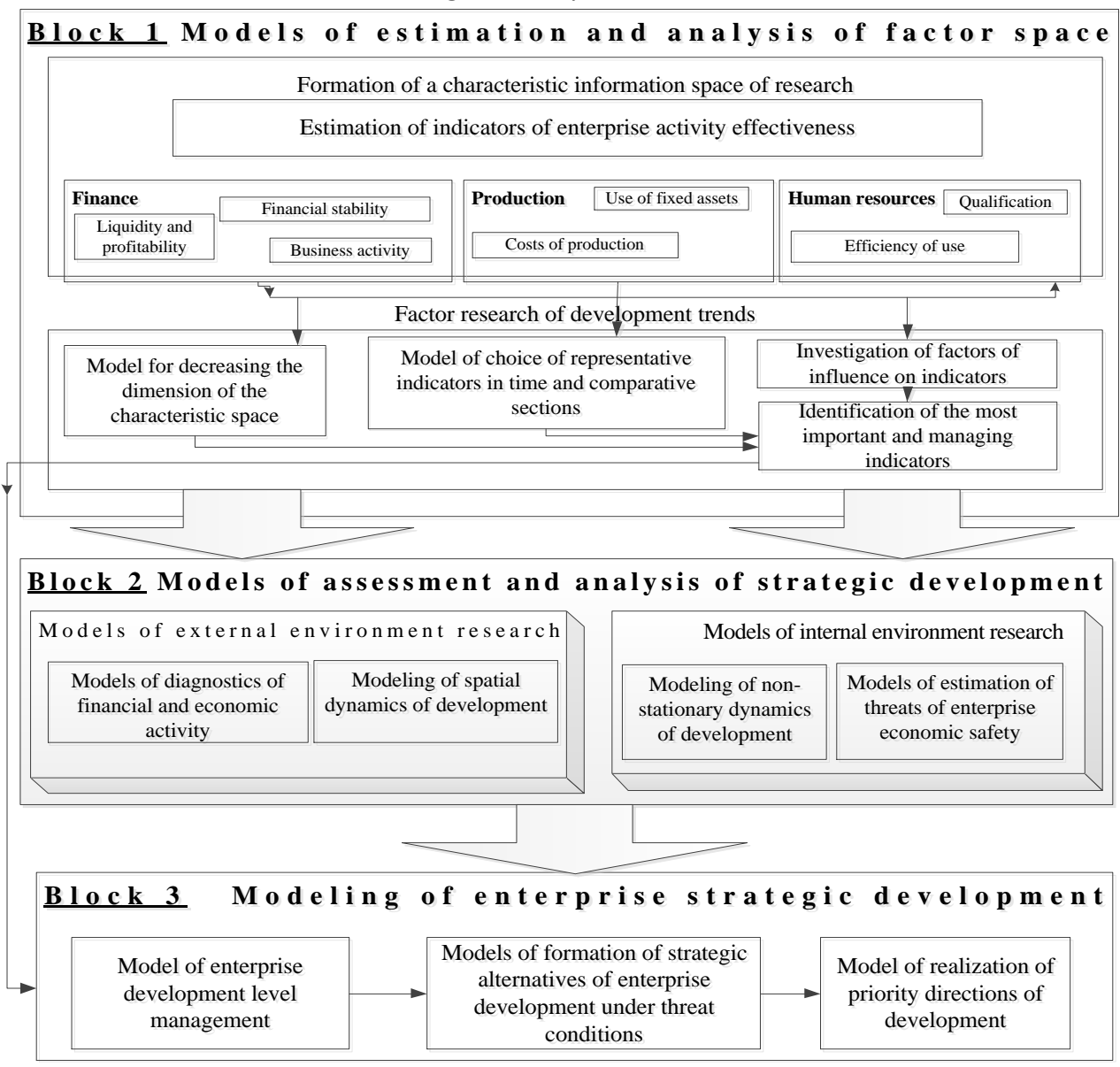

Source: developed by the authors

The advantages and disadvantages of the proposed methods of conceptual scheme are given in Table 2 . 
Table 2

The advantages and disadvantages of the proposed methods of conceptual scheme

\begin{tabular}{|c|c|c|c|}
\hline $\begin{array}{c}\text { The name of the } \\
\text { mechanism of } \\
\text { strategic } \\
\text { development }\end{array}$ & Basic scientific approaches & Advantages & Disadvantages \\
\hline $\begin{array}{l}\text { Mechanisms for } \\
\text { assessing and } \\
\text { analyzing the factor } \\
\text { space of enterprise } \\
\text { strategic } \\
\text { development }\end{array}$ & $\begin{array}{l}\text { Estimation and analysis of } \\
\text { factor space on the bases of: } \\
\text { - factor-functional analysis; } \\
\text { - expert evaluation; } \\
\text { - integral assessment. }\end{array}$ & $\begin{array}{l}\text { - identification of key development } \\
\text { factors; } \\
\text { - the necessary list of indicators for } \\
\text { spatial-dynamic-comparative analysis; } \\
\text { - use of factual statistics data; } \\
\text { - outlining the boundaries between } \\
\text { the goals and opportunities. }\end{array}$ & $\begin{array}{l}\text { - lack of unambiguous standard } \\
\text { approaches to the formation of factor } \\
\text { space through a wide range of available } \\
\text { techniques; } \\
\text { - certain static data when compared } \\
\text { with others; } \\
\text { - taking into account the large amount } \\
\text { of input data complicates the process of } \\
\text { evaluation and analysis; } \\
\text { - significant cost of resources for the } \\
\text { information collection and processing. }\end{array}$ \\
\hline $\begin{array}{l}\text { Mechanisms for } \\
\text { assessing and } \\
\text { analyzing the } \\
\text { internal and } \\
\text { external } \\
\text { environment of } \\
\text { enterprise strategic } \\
\text { development }\end{array}$ & $\begin{array}{l}\text { Assessment and analysis of } \\
\text { enterprise strategic } \\
\text { development on the bases of } \\
\text { research: } \\
\text { - available development } \\
\text { potential; } \\
\text { - competitiveness level; } \\
\text { - integral development level; } \\
\text { - internal strengths and } \\
\text { weaknesses; } \\
\text { - external macro- and } \\
\text { microenvironment. }\end{array}$ & $\begin{array}{l}\text { - coverage of the whole set of } \\
\text { processes, which allows us to identify } \\
\text { reserves in the enterprise activities; } \\
\text { - assessment of compliance of the } \\
\text { potential stage of development; } \\
\text { - the ability to take into account the } \\
\text { specifics of the industry; } \\
\text { - the ability to identify a reference } \\
\text { leader in the industry; } \\
\text { - calculation of the rating assessment } \\
\text { of particular enterprise development } \\
\text { taking into account qualitative and } \\
\text { quantitative indicators. }\end{array}$ & $\begin{array}{l}\text { - the difficulty of choosing only one } \\
\text { optimal technique; } \\
\text { - development assessment does not } \\
\text { always make possible to determine the } \\
\text { real scale and standards; } \\
\text { - subjectivity of evaluation indicators; } \\
\text { - conclusions are more intended to } \\
\text { identify problem situations; } \\
\text { - qualitative economic interpretation is } \\
\text { not always possible. }\end{array}$ \\
\hline $\begin{array}{l}\text { Mechanisms for } \\
\text { modeling and } \\
\text { managing the } \\
\text { enterprise strategic } \\
\text { development }\end{array}$ & $\begin{array}{l}\text { Modeling and management of } \\
\text { strategic development on the } \\
\text { bases of: } \\
\text { - multi-criteria assessment of } \\
\text { the enterprise development } \\
\text { level; } \\
\text { - assessment of development } \\
\text { trends by phases of enterprise } \\
\text { cycle, global cycles, trends; } \\
\text { - forecasting taking into } \\
\text { account the effects of long- } \\
\text { term memory and assessments } \\
\text { of the current situation; } \\
\text { - simulation and optimization } \\
\text { of management processes. }\end{array}$ & $\begin{array}{l}\text { - the possibility of aggregation of } \\
\text { qualitative and quantitative } \\
\text { indicators; } \\
\text { - taking into account the opinions of } \\
\text { experts and business leaders; } \\
\text { - multicriteria evaluation for } \\
\text { determation the development } \\
\text { sustainability by a set of gradations } \\
\text { for each criterion; } \\
\text { - the ability of evaluation at set } \\
\text { intervals and selected development } \\
\text { stages; } \\
\text { - the ability to obtain real forecasts; } \\
\text { - development of future scenarios and } \\
\text { formation of the corresponding } \\
\text { development strategy; } \\
\text { - excellent presentation of results due } \\
\text { to graphic and visual means. }\end{array}$ & $\begin{array}{l}\text { - lack of generally accepted valuation } \\
\text { model due to the difficulty of } \\
\text { identifying each individual object; } \\
\text { - the complex procedural nature of } \\
\text { development is not fully taken into } \\
\text { account; } \\
\text { - evaluation to a greater extent reflects } \\
\text { the changes taking place without } \\
\text { identifying their sources; } \\
\text { - lack of possibility to form a complex } \\
\text { aggregate assessment; } \\
\text { - lack of clear evaluation parameters, } \\
\text { complexity of application of models in } \\
\text { modern conditions. }\end{array}$ \\
\hline
\end{tabular}

For implementation of proposed models were used the following application and software: MS Excel, Statistica, Matlab, EViews, Vensim_Ple, Statistica Neuro Network, Gretl.

\section{Results}

The diagnostics models of industrial systems financial and economic activity provide a phased implementation of complex of models: classification, recognition, evaluation and forecasting. The iterative and hierarchical methods of cluster analysis are used for building models of classification of enterprises financial and economic activity.

The diagnostics models of industrial systems financial and economic activity consist of models:

- models of classification and formation of enterprise states classes; 
- models of recognition of enterprise financial situations;

- models of assessing of enterprise financial and economic state;

- neural network models of forecasting of financial and economic activity state.

The analysis was carried out for 23 machine-building enterprises of Kharkiv region of Ukraine in $2013-2017$ years. As a result of the classification three groups of enterprises with normal (I), satisfactory (II) and unsatisfactory (III) states of financial and economic activity were received. Recognition of situations was carried out on the basis of discriminant functions which were identified for groups of relevant indicators for each spheres of business. The values of coefficients of discriminant variables and constants of discrimination (C) in terms of liquidity and profitability, as well as recognition quality criterion value $(\lambda)$ during the analyzed period are presented in Table 3.

The values of criterion ( $\lambda$ ) Wilkes is close to zero. It confirms the possibility of using the discriminant function in assessing the state of the analyzed companies. Similar researches were conducted for all groups for all spheres of business.

Table 3

Discriminant function in terms of liquidity and profitability

\begin{tabular}{|c|c|c|c|c|c|c|c|c|}
\hline \multirow[b]{2}{*}{ Year } & \multirow[b]{2}{*}{$\begin{array}{l}\text { Class of financial } \\
\text { and economic state }\end{array}$} & \multicolumn{5}{|c|}{ Indicators } & \multirow[b]{2}{*}{$\begin{array}{l}\text { Discriminatio } \\
\text { n constants } \\
\text { (C) }\end{array}$} & \multirow[b]{2}{*}{$\begin{array}{c}\text { Quality } \\
\text { criterion } \\
\text { Wilks' L }(\lambda)\end{array}$} \\
\hline & & $\begin{array}{c}\text { Absolute } \\
\text { liquidity ratio }\end{array}$ & $\begin{array}{c}\text { Coefficient of } \\
\text { urgent } \\
\text { liquidity }\end{array}$ & $\begin{array}{l}\text { Return on } \\
\text { total capital }\end{array}$ & $\begin{array}{l}\text { Return on } \\
\text { equity }\end{array}$ & $\begin{array}{l}\text { Net return } \\
\text { on sales }\end{array}$ & & \\
\hline \multirow{3}{*}{2013} & 1 & 196,071 & 34,964 & 103,199 & $-112,12$ & 12,269 & $-372,018$ & 0,00118 \\
\hline & II & $-19,464$ & $-2,5139$ & $-13,881$ & 15,1194 & 0,1977 & $-4,1387$ & \\
\hline & III & $-16,697$ & $-5,3556$ & 0,3026 & $-0,4249$ & $-4,5839$ & $-7,8920$ & \\
\hline \multirow{3}{*}{2014} & 1 & 244,89 & 50,48 & $-94,51$ & 43,70 & $-19,21$ & $-390,09$ & 0,00369 \\
\hline & II & $-31,21$ & $-7,70$ & 14,14 & $-6,33$ & 4,39 & $-7,73$ & \\
\hline & III & $-14,65$ & $-1,63$ & 3,35 & $-1,78$ & $-0,99$ & $-3,47$ & \\
\hline \multirow{3}{*}{2015} & 1 & 428,09 & $-40,81$ & $-123,76$ & 87,05 & 42,25 & $-598,63$ & 0,00118 \\
\hline & II & $-37,36$ & 3,90 & 7,48 & $-4,15$ & $-1,91$ & $-5,06$ & \\
\hline & III & $-61,23$ & 3,79 & 37,60 & $-33,13$ & $-16,68$ & $-31,36$ & \\
\hline \multirow{3}{*}{2016} & I & 12,29 & 8,65 & 21,64 & $-16,30$ & 10,36 & $-31,06$ & 0,01319 \\
\hline & II & $-1,21$ & 0,07 & 1,33 & $-2,18$ & 3,28 & $-1,08$ & \\
\hline & III & $-4,36$ & $-6,79$ & $-21,54$ & 20,96 & $-20,88$ & $-25,06$ & \\
\hline \multirow{3}{*}{2017} & I & $-1,21$ & 14,25 & $-15,33$ & 18,72 & 11,66 & $-23,62$ & 0,00562 \\
\hline & II & $-1,21$ & $-0,09$ & $-13,23$ & 16,78 & 10,77 & $-2,65$ & \\
\hline & III & 8,08 & $-8,97$ & 89,58 & $-113,16$ & $-72,37$ & $-108,14$ & \\
\hline
\end{tabular}

Source: developed by the authors

The neural network models are used for determination the probability of getting of analyzed enterprises in some class of financial and economic state and prediction of their activity. The best type of network is MLP (multilayer perceptron) for each of the studied groups of indicators by spheres of their business activity.

Table 4 shows the results of forecasting of financial and economic activity of JSC "Harverst". The high quality of the forecast confirms the value of the error and correlation coefficient. The values of probability suggest that the financial and economic state of the enterprise as a whole can be classified as Class II and considered as satisfactory, but the company has potential of development in financial and labor sectors. 
Table 4

Results of neural network model of forecasting of JSC «Harverst» state

\begin{tabular}{|c|c|c|c|c|c|c|c|c|c|}
\hline \multirow{3}{*}{$\begin{array}{l}\text { Groups of financial and economic } \\
\text { indicators for spheres of vital activity }\end{array}$} & \multirow{3}{*}{$\begin{array}{l}\text { Type of best } \\
\text { network }\end{array}$} & \multirow{3}{*}{$\begin{array}{l}\text { Net- } \\
\text { work } \\
\text { error }\end{array}$} & \multirow{3}{*}{$\begin{array}{l}\text { The } \\
\text { correlation } \\
\text { coefficient }\end{array}$} & \multicolumn{6}{|c|}{$\begin{array}{c}\text { The probability of getting enterprises in each class } \\
\text { selected states }\end{array}$} \\
\hline & & & & \multicolumn{3}{|c|}{ (2017 year) } & \multicolumn{3}{|c|}{ (2018 year) } \\
\hline & & & & 1 & II & III & I & II & III \\
\hline Liquidity and profitability & $M L P$ & 0,012 & 0,95 & 0,14 & 0,60 & 0,26 & 0,11 & 0,63 & 0,26 \\
\hline Business activity & $M L P$ & 0,023 & 0,97 & 0,87 & 0,10 & 0,03 & 0,91 & 0,06 & 0,03 \\
\hline Financial stability & $M L P$ & 0,019 & 0,97 & 0,29 & 0,53 & 0,18 & 0,27 & 0,54 & 0,19 \\
\hline Fixed assets & $M L P$ & 0,014 & 0,93 & 0,62 & 0,38 & 0,00 & 0,41 & 0,54 & 0,05 \\
\hline Production costs & $M L P$ & 0,036 & 0,90 & 0,22 & 0,44 & 0,34 & 0,27 & 0,56 & 0,17 \\
\hline Efficiency of human resources using & $M L P$ & 0,051 & 0,91 & 0,96 & 0,04 & 0,00 & 0,91 & 0,09 & 0,00 \\
\hline Qualification & $M L P$ & 0,006 & 0,98 & 0,73 & 0,27 & 0,00 & 0,51 & 0,42 & 0,07 \\
\hline
\end{tabular}

Source: developed by the authors

To study the dynamic characteristics and identify common trends of enterprises development the complex of models of research of spatial dynamics development is built (Figure 1).

The research of the dynamics of enterprises development both for the activity spheres, and for the whole set of the investigated enterprises is made on the bases of values of local and general integral indicators of development level which are calculated by taxonomy method. The auto-regression models on panel data are used for prediction the values of integral indicators. These models have such general form:

$$
I_{j i}=c_{j i}+a \cdot I_{j i}(t-1)+\varepsilon_{j i},
$$

where $l_{j i}$ - value of integral indicator of development level in $j$-th group of financial and economic indicators for the relevant activity spheres ( $j=1 \div 7$ ) for $\mathrm{i}$-th enterprise ( $i=1 \div 23$ ); $c_{j i}$ - models coefficients (fixed effects) which reflect both general trend of engineering enterprises for the studied spheres, and particular qualities of their development; $a$ - vector of model parameters; ${ }_{i j}$-random error.

Research complex models spatial dynamics of enterprise development includes:

1) Models of research of development dynamics:

- construction of complex of integral indicators of development level on the basis of taxonomy method which is presented in Pluta (1980);

- model of estimation of local integral indicators of development level by groups of financial and economic indicators for enterprise spheres of activity;

- model for estimating the overall integral index of enterprise development level.

2) Models of assessment and analysis of development level include:

- construction of a set of panel data models (these models are described in Soshnikova, Tamashevich (1999) and Wooldridge (2002);

- models of panel data of dynamics of development on the basis of local integral indicators for spheres of activity;

- model for assessing the impact of local integral indicators on the general indicator of development level;

- models of panel data of enterprise development dynamics by the general integral indicator; 
- models of specification and research of individual effects of development dynamics.

3) Models of development dynamics forecasting include:

- autoregressive models of forecasting of enterprise development level indicators;

- forecasting of local integral indicators of development level by groups of financial and economic indicators for the enterprise spheres of activity;

- forecasting of the general integral indicator of enterprise development level.

Existing models of development dynamics forecasting are presented in Guryanova, Klebanova \& Prokopovich (2016).

Table 5

Panel data models of dynamics of industrial systems development

\begin{tabular}{|c|c|c|c|c|}
\hline $\begin{array}{c}\text { Total indicator for the } j \text {-th group of } \\
\text { financial and economic indicators for } \\
\text { spheres of activity }\end{array}$ & $\begin{array}{c}\text { Type of autoregressive panel } \\
\text { data model }\end{array}$ & $\begin{array}{c}\text { Determination } \\
\text { coefficient } \\
\text { (R-squared) }\end{array}$ & $\begin{array}{c}\text { Durbin- } \\
\text { Watson } \\
\text { Criterion } \\
\text { (DW) }\end{array}$ & $\begin{array}{c}\text { Student test } \\
\text { (t) }\end{array}$ \\
\hline Liquidity and profitability $\left(I_{1}\right)$ & $I_{1}=c_{i}+0,19 \cdot I_{1(t-1)}$ & 0,9948 & 2,143 & 4,84 \\
\hline Business activity $\left(I_{2}\right)$ & $I_{2}=c_{i}+0,12 \cdot I_{2(t-1)}$ & 0,9966 & 2,084 & 9,94 \\
\hline Financial stability $\left(I_{3}\right)$ & $I_{3}=c_{i}+0,33 \cdot I_{3(t-1)}$ & 0,9922 & 2,045 & 12,70 \\
\hline Fixed assets $\left(I_{4}\right)$ & $I_{4}=c_{i}-0,18 \cdot I_{4(t-1)}$ & 0,9805 & 2,175 & 2,98 \\
\hline Production costs $\left(I_{5}\right)$ & $I_{5}=c_{i}-0,2 \cdot I_{5(t-1)}$ & 0,9774 & 2,006 & 5,82 \\
\hline Efficiency of human resources using $\left(I_{6}\right)$ & $I_{6}=c_{i}-0,19 \cdot I_{6(t-1)}$ & 0,8744 & 2,064 & 21,53 \\
\hline Qualification $\left(I_{7}\right)$ & $I_{7}=c_{i}-0,28 \cdot I_{7(t-1)}$ & 0,983 & 1,985 & 3,62 \\
\hline Total integral indicator $\left(I_{t o t}\right)$ & $I_{t o t}=c_{i}-0,029 \cdot I_{t o t(t-1)}$ & 0,9662 & 2,179 & 2,93 \\
\hline
\end{tabular}

Source: developed by the authors

The criteria for adequacy (coefficient of determination, Durbin-Watson criterion, Student test) confirmed the possibility of using the fixed effects model for prediction of local and general integral indicators. The models of unsteady dynamics and assessment of threats to the economic security of the enterprise are proposed as tools for research the internal environment of the enterprise development.

For investigation the unsteady dynamics of the company (Figure 1) we use error correction models (ECMmodels). The implementation of this algorithm is carried out on the initial data of integrated indicators of JSC "Harverst" development level in terms of nine years (2008 - 2017 years) for every month of these years for such spheres as finance (I_FINANCE), production (I_PRODUCTION), human resources (I_LABOR) and complex indicator (I_COMPLEX).

The models complex of research of unsteady dynamics of the spheres of enterprise on the bases of ECM-analysis (the methodology of ECM-analysis is presented in Guryanova, Klebanova \& Prokopovich (2016), Raudys (2001)) and consist of: models of research of development dynamics of enterprise activity spheres; models of long-term interaction of enterprise business spheres; models of nonlinear dynamics of development of activity spheres; models of stability and forecasting of development dynamics of enterprise activity spheres.

Quality check of obtained models by Akaike's and Schwarz criteria shows their adequacy, which makes possible to use them for analysis the importance of factors of influencing the dynamics of a particular variable of system and this check is an important basis for decision-making regarding the formation of strategic alternatives of development. 
Predictions which are based on ECM models used for analyzing trends in the future development of the company allow us to determine patterns of development, the interrelation between the studied activity spheres and degree of their impact on the general level of development.

The development of model for assessing threats to economic security is important for the formation and implementation of alternatives of development (Figure 1). In order to more adequately and systematically examine the internal environment state as the potential of strategic development it is necessary to identify and classify the totality of threats to internal and external environment affecting the safety and undertake a complex assessment of the threats and determine the level of interraction between the studied categories. Consequently, complex analysis of the internal environment is impossible without systematic study and modeling of threats to economic security. The model of complex dynamic assessment of threats to economic security for the two components is proposed in this paper. This model has analytical and applied aspect and includes the following steps (Figure 2).

Figure 2

Analytical and applied model of threats assessment of internal and external environment of enterprise economic security

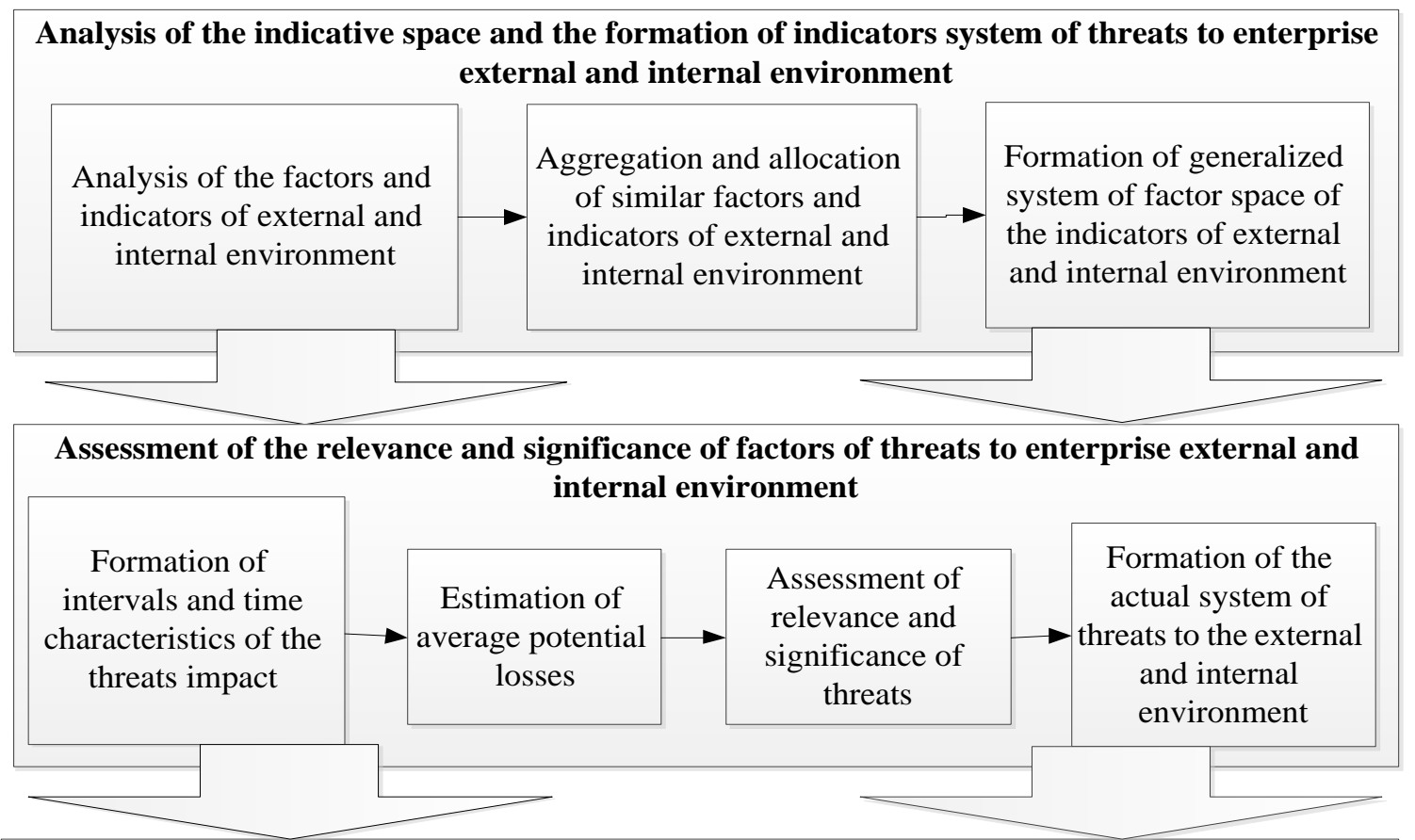

Assessment of local and general integral indicators of threats to external and internal factors

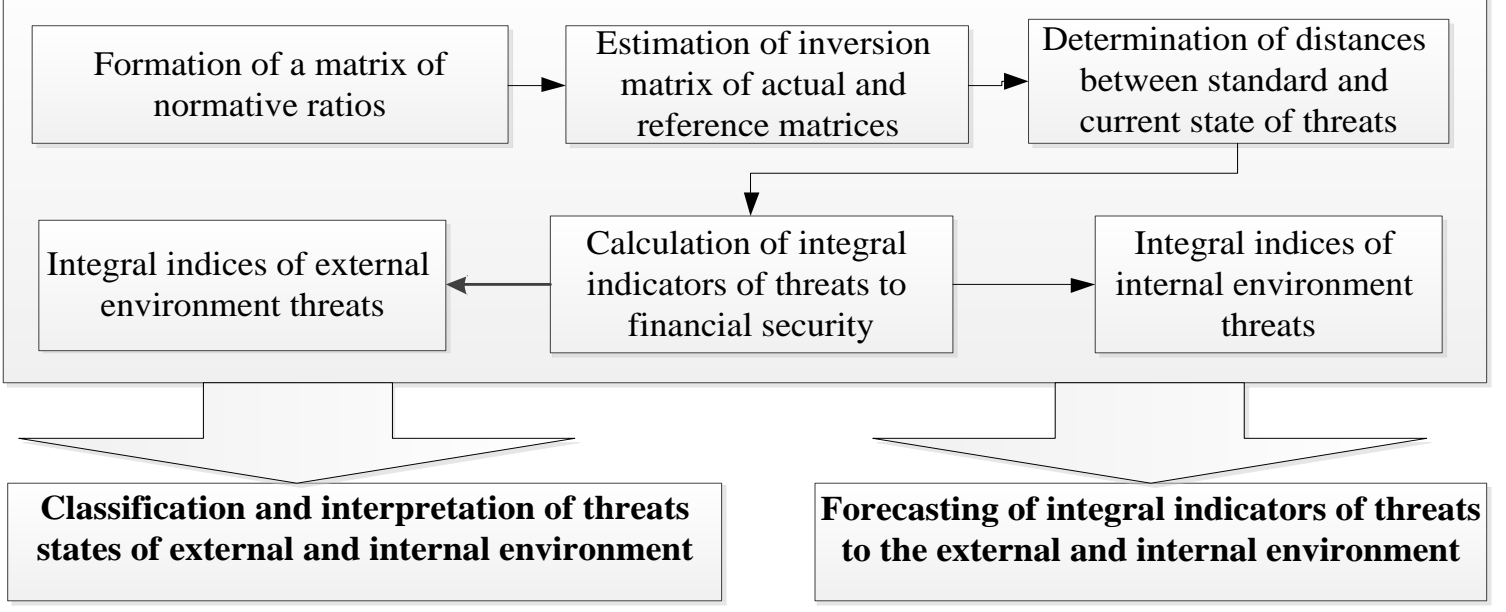

Source: developed by the authors 
Total integral indicator of internal environment threats is:

$$
\begin{aligned}
& I_{-} \text {tot } \text { int }_{i t}=\left(\left\{I_{-} \operatorname{int}(h r)_{1_{-} i t}\right\},\left\{I_{-} \operatorname{int}(m p)_{2_{-} i t}\right\},\left\{I_{-} \operatorname{int}(c a p)_{3_{-} i t}\right\},\right. \\
& \left.\left\{I_{-} \operatorname{int}(t e c h)_{4_{-} i t}\right\},\left\{I_{-} \operatorname{int}(m a n)_{5_{-} i t}\right\}\right)
\end{aligned}
$$

where $I_{-}$int $_{j_{-} i t}-$ local components of threats of internal environment for $i$-th enterprises $(i=1 \div 7)$ in the same period of time $t(\mathrm{t}=1 \div 5) ; I_{-} \operatorname{int}(h r)_{1 \_i t}$ - human resources; $I_{-} \operatorname{int}(m p)_{2 \_i t}$ - means of production; $I_{-} \operatorname{int}(\mathrm{cap})_{3_{-} i t}$-capital; $I_{-} \operatorname{int}(\text { tech })_{4_{-} i t}$-technologies; $I_{-} \operatorname{int}(\text { man })_{5_{-} i t}$ - management; $I_{-} t_{\text {tot }}$ int ${ }_{i t}$ - total general indicator of threats to the internal environment for $i$-th enterprise $(i=1 \div 7)$ in the same period of time $t($ $\mathrm{t}=1 \div 5$ ).

Total integral indicator of the external environment threats is:

$$
\begin{aligned}
& I_{-} \text {tot_ext }=\left(\left\{I_{-} \operatorname{ext}(s p)_{1_{-} t}\right\},\left\{I_{-} \operatorname{ext}(\operatorname{ssp})_{2_{-} t}\right\},\left\{I_{-} \operatorname{ext}(\text { macro })_{3_{-} t}\right\},\right. \\
& \left.\left\{I_{-} \text {ext }(\text { market })_{4_{-} t}\right\},\left\{I_{-} \text {ext }(\text { bank })_{5_{-} t}\right\},\left\{I_{-} \operatorname{ext}(\text { fisc })_{6_{-} t}\right\},\left\{I_{-} \operatorname{ext}(\operatorname{sm})_{7_{-} t}\right\}\right)
\end{aligned}
$$

where $I_{-} e x t_{j_{-} t}-$ local components of threats of the external environment in the same period of time $t$ ( $\mathrm{t}=1 \div 5) ; I_{\_} \operatorname{ext}(s p)_{1_{-} t}$ - social and political; $I_{-} \operatorname{ext}(\operatorname{ssp})_{2_{-} t}$ - strategic state position; $I_{\_}$ext $(\text {macro })_{3_{-} t}-$ macroeconomic; I_ext(market $)_{4 \_t}$ - market; I_ext(bank $)_{5_{-} t}$ - banking; I_ext (fisc $)_{6 \_t}$ - fiscal; $I_{-} \operatorname{ext}(\mathrm{sm})_{7_{-} t}$ - stock market; $I_{-}$tot ${ }_{-}$ext $t_{t}$ - total general indicator of threats to the external environment in the same period of time $t(\mathrm{t}=1 \div 5)$.

Determination of dominant threats is made on the bases of the assessment of their significance and which involves the calculation of average potential losses from threats action and their relevance. The values of average losses ( $\bar{C}^{i}$ ) on the $i$-th interval are calculated and ranked as follows:

$$
\bar{C}^{i}=\sum_{k} p_{k}^{i} C_{k}^{i}
$$

where $p_{k}^{i}$ - probability of realization of $k$-th scenario of threats activity on $\mathrm{i}$-th interval; $C_{k}^{i}-$ value of potential losses for the $k$-th scenario of threats activity on $i$-th interval.

Evaluation of threats relevance $(\delta T)$ is determined as follows:

$$
\delta T=\frac{\Delta T_{r e s}}{\Delta T_{r e d}}=\frac{\Delta t^{*}(i-1 / 2)}{\Delta T_{i}^{m}},
$$

where $\Delta T_{\text {res }}$ - time to start of threat;

$\Delta T_{\text {red }}$ - time for the preparation and adoption of preventive measures.

The model for complex dynamic assessment of threats to economic security $(U)$ is built in this paper. This model is based on a comparison of actual and normative values of indicators that reflect the strengths of threats of the enterprise and is calculated as follows: 
$U=1-\frac{\sum_{\alpha=1}^{A} \sum_{\delta=1}^{B} a_{\alpha \delta}^{\prime}}{i(i-1)}$

where $a_{\alpha \delta}^{\prime}$ - elements of the matrix inversions; $i-$ number of indicators which are analyzed.

The values of complex assessment vary from 0 to $1,(U)=1$ defines ideal or standard status of economic security. Considering the threats action in the development of strategies makes possible to determine the set of safe system states in general and for spheres (local components) and calculate the effective trajectory of system behavior.

The list of dominant threats which form integral indicators of threats to the investigated enterprise is presented in Table 6.

Table 6

Dominant threats to

the enterprise activity

\begin{tabular}{|c|c|c|c|}
\hline $\begin{array}{c}\text { Threats (risks) } \\
\begin{array}{c}\text { Threat of delayed the shipment of finished } \\
\text { products }\end{array}\end{array}$ & $R_{1}^{F}$ & The threat of reducing the raw materials quality & $R_{6}^{V}$ \\
\hline $\begin{array}{c}\text { Threat of fines accrual in case of late repayment } \\
\text { of current liabilities }\end{array}$ & $R_{2}^{F}$ & The threat of moral and physical depreciation of \\
assets & $R_{7}^{V}$ \\
\hline Threat of increase of interest rates on loans & $R_{3}^{F}$ & The threat of increase in staff turnover & $R_{8}^{K}$ \\
\hline Threat of rising prices for raw materials & $R_{4}^{F}$ & The threat of reduction in staff qualification level & $R_{9}^{K}$ \\
\hline Threat of untimely delivery of raw materials & $R_{5}^{V}$ & The threat of reduction in payroll & $R_{10}^{K}$ \\
\hline
\end{tabular}

Source: developed by the authors

The proposed models of threats assessment to economic security will improve a process which is aimed at preventing and localization of threats to internal and external environment in the development of strategic events for various local components and time horizons and identify the company's ability to follow the strategic goals of development and to fulfill its mission.

Scenario management model of enterprise development level is presented in such form:

$U_{p r}=\langle P, L, R, A\rangle$, ,

where $P$ - available resources of enterprise activity spheres (development potential); $L$ - criteria for achieving development goals (limitations); $R$ - threats to enterprise development (risks); $A$ - alternatives to enterprise development.

The formation of three strategies is made under this model: development strategy; recognition situations strategy; situations management strategy.

Three strategies are management development scenarios. The effectiveness of management strategies is determined by the degree of usefulness, the effectiveness of development strategy - by integral expected result, the effectiveness of recognition strategy is determined by the degree of threats action. 
The bases of the models of the formation of development strategic alternatives in the conditions of threats action (Fig. 1) is the concept of system dynamics and scenario approach. In the process of simulation model building it is used flow diagram of interrelations with key elements: products supplies formation; formation of production costs; production and sales; receivables formation; formation of fixed assets; formation of funds; formation of net profit. The implementation of this model involves identification of diagnostic features for the company spheres, the resulting variables of management, the range of their changes taking into account the degree of threats impact, which makes possible to plan experiments.

Figure 3

Simulation model of the enterprise activity in terms of threats to internal and external environment (fragment)

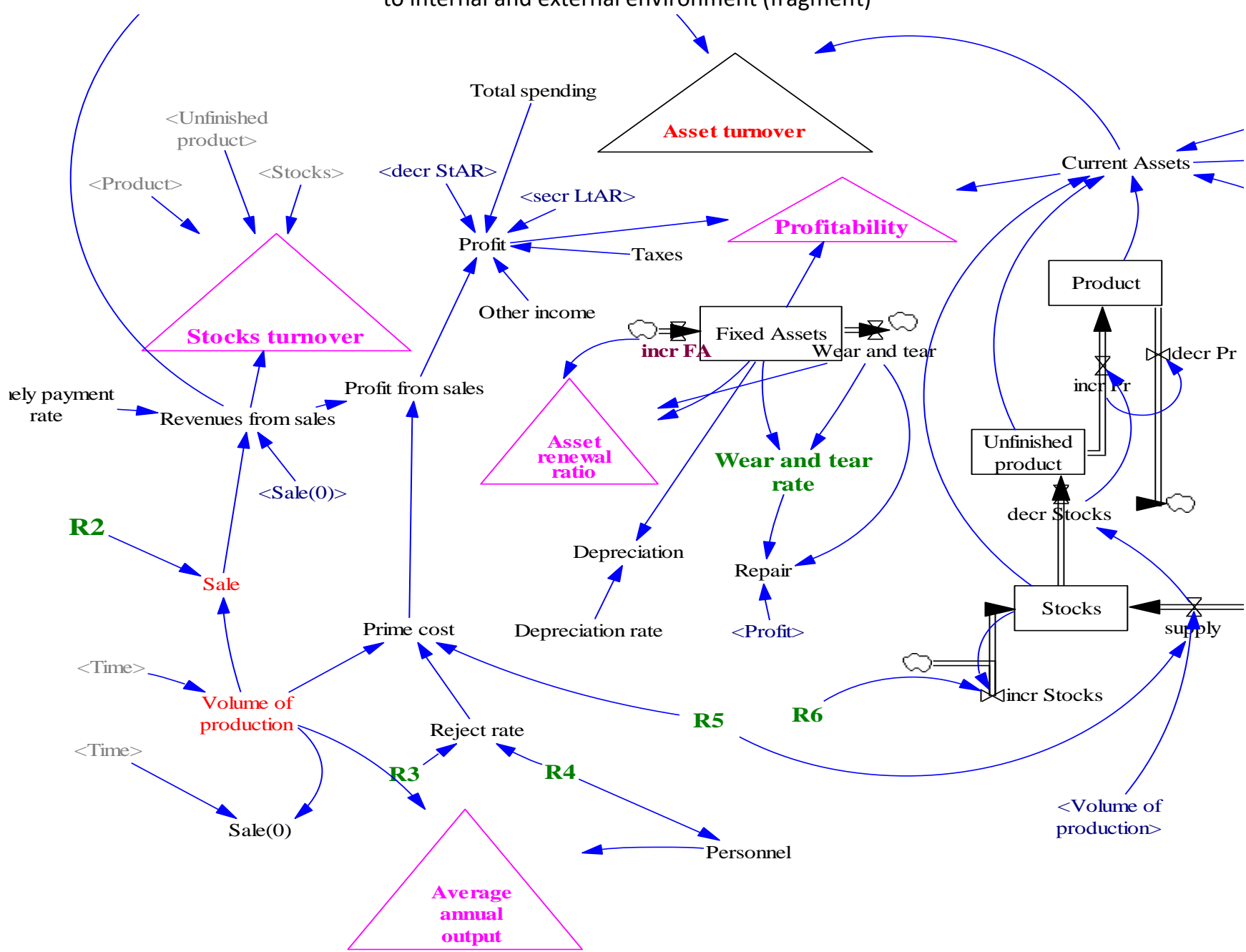

Source: developed by the authors

The simulation model, fragment of which is shown in Figure 3, makes possible to simulate the enterprises financial flows, identify predictive output characteristics of their activities and assess the threats impact. The methodology of simulation model construction is presented in Dubois, Godun, Orlenko, Sendzyuk \& Duggan (2016), Leonenkov (2003). In accordance with the experiments plan we have conducted simulation of crisis scenarios (optimistic, realistic and pessimistic) on the enterprise indicators, taking into account the trends of the company and threats impact force (fragment of results is shown in Figure 4).

The proposed simulation model of the enterprise activity has the following advantages: 
- enough universal character;

- covers all the main elements of the industrial system;

- makes possible to do multivariate calculations at different threats impact levels and their combinations;

- is a prerequisite for the development of the most appropriate preventive actions;

- makes possible to evaluate the effects of random events that can occur in the external or internal environment.

Figure 4

Simulation experiments results (fragment)
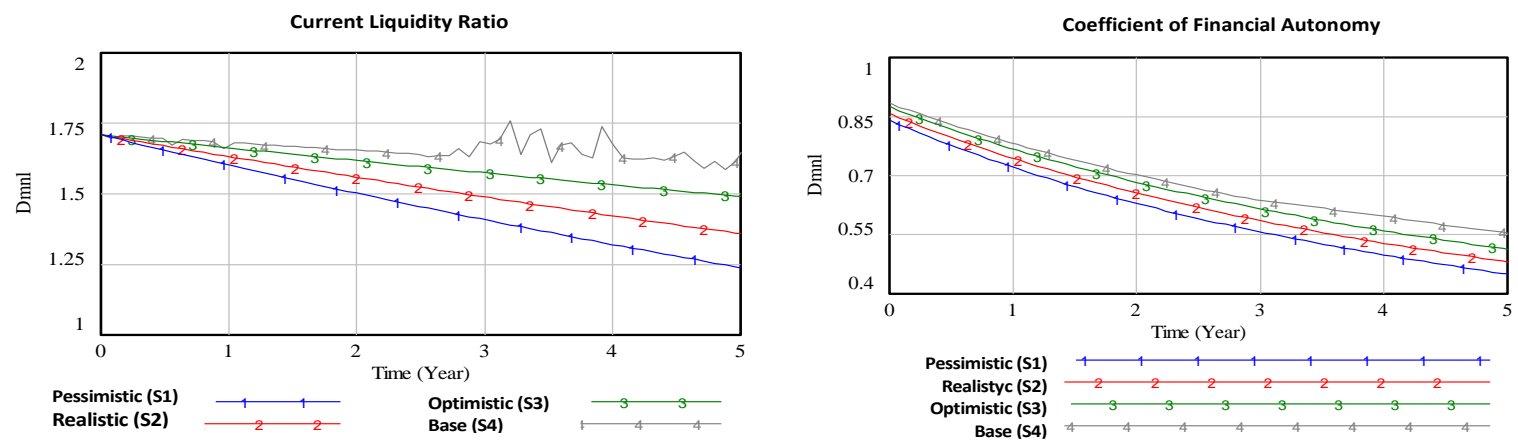

Turnover Rate of Inventories
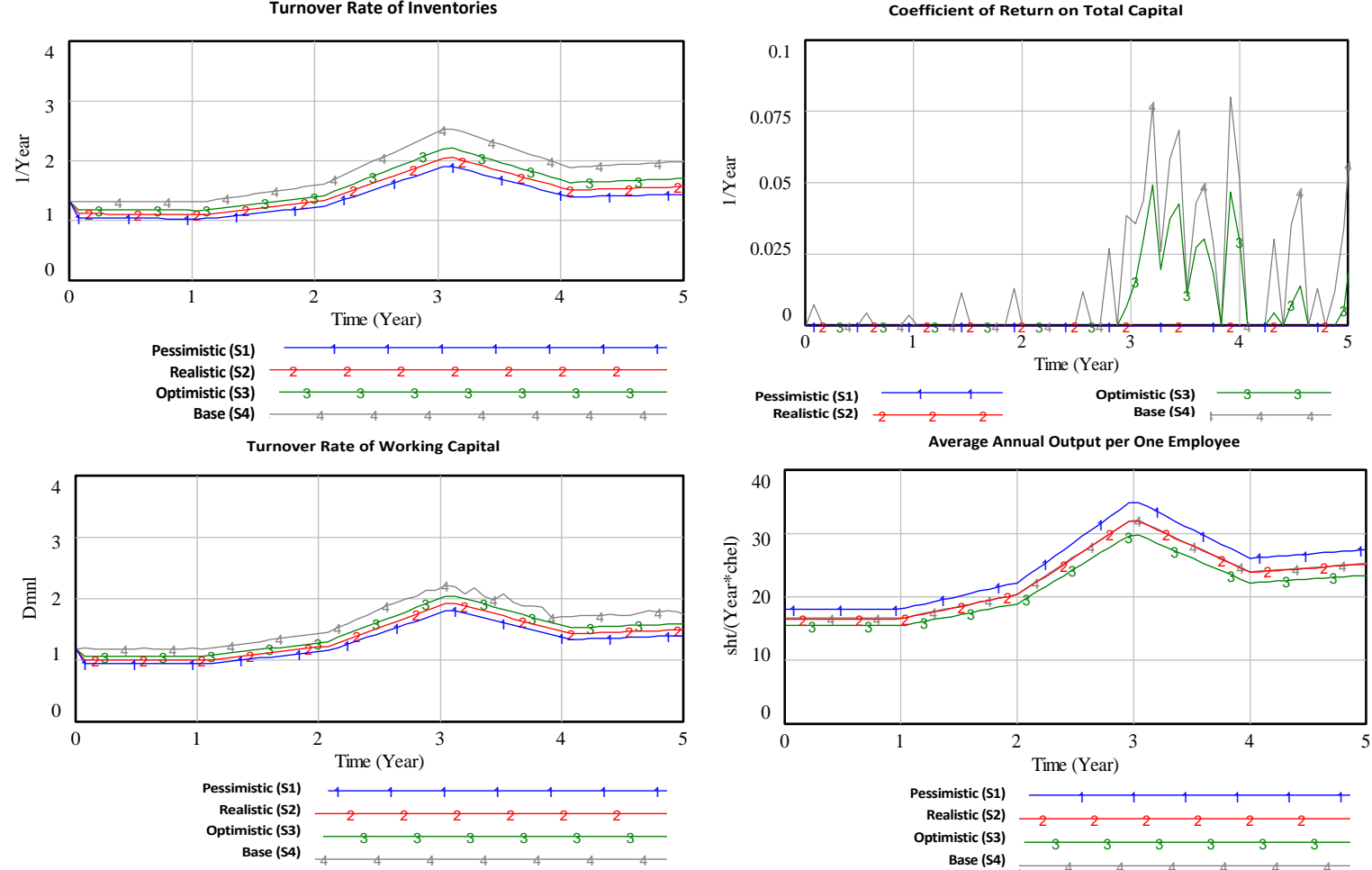

Source: developed by the authors

The model of choice of enterprise development alternatives on the basis of fuzzy logic rules (Dubois, Duggan (2016)) is built for generation possible strategies for enterprise development on the bases of the impact of threats. The range of functions changes of threats activity by linguistic variables on general development level is shown in Table 7. 
Table 7

The range of functions for linguistic variables (fragment)

\begin{tabular}{|c|c|c|}
\hline Threat & Linguistic variable & Function of belonging \\
\hline \multirow{3}{*}{$\begin{array}{l}R_{1}^{F} \\
\text { The threat of delayed the } \\
\text { shipment of finished } \\
\text { products }\end{array}$} & Optimistic threat level & $\mu(x)=z m f(0.1 ; 0.125)$ \\
\hline & Realistic threat level & $\mu(x)=\operatorname{gaussmf}(0.027 ; 0.15)$ \\
\hline & Pessimistic threat level & $\mu(x)=\operatorname{smf}(0.176 ; 0.2)$ \\
\hline \multirow{3}{*}{$\begin{array}{l}\qquad R_{2}^{F} \\
\text { The threat of fines in the } \\
\text { event of late repayment of } \\
\text { current liabilities }\end{array}$} & Optimistic threat level & $\mu(x)=z m f(0.02 ; 0.043)$ \\
\hline & Realistic threat level & $\mu(x)=$ gaussmf $(0.01 ; 0.05)$ \\
\hline & Pessimistic threat level & $\mu(x)=\operatorname{smf}(0.055 ; 0.07)$ \\
\hline$\ldots \ldots$ & ................... & ................. \\
\hline \multirow{5}{*}{$\begin{array}{c}\Delta I \\
\text { The range of fluctuation in } \\
\text { the general level } \\
\text { development }\end{array}$} & Low level & $\mu(x)=\operatorname{smf}(-0.02 ;-0.0165)$ \\
\hline & Below average level & $\mu(x)=\operatorname{gaussmf}(0.00164 ;-0.0185)$ \\
\hline & Average level & $\mu(x)=\operatorname{gaussmf}(0.00161 ;-0.021)$ \\
\hline & Above average level & $\mu(x)=\operatorname{gaussmf}(0.00218 ;-0.0235)$ \\
\hline & High level level & $\mu(x)=z m f(-0.025 ;-0.0225)$ \\
\hline
\end{tabular}

Source: developed by the authors

Thus, the rules of fuzzy logical conclusion on the bases of Mamdani algorithm are formed and used to select enterprise development alternatives in terms of threats. Mamdani algorithm is presented in Heckman, Amsterdam (2007).

Using scenario modeling the possible scenarios of the enterprise are generalized for the range of changes and predicted values of economic results of their implementation are obtained (Figure 5).

Figure 5

Expected values of integrated indicators dynamics by activity scenarios under the threats action

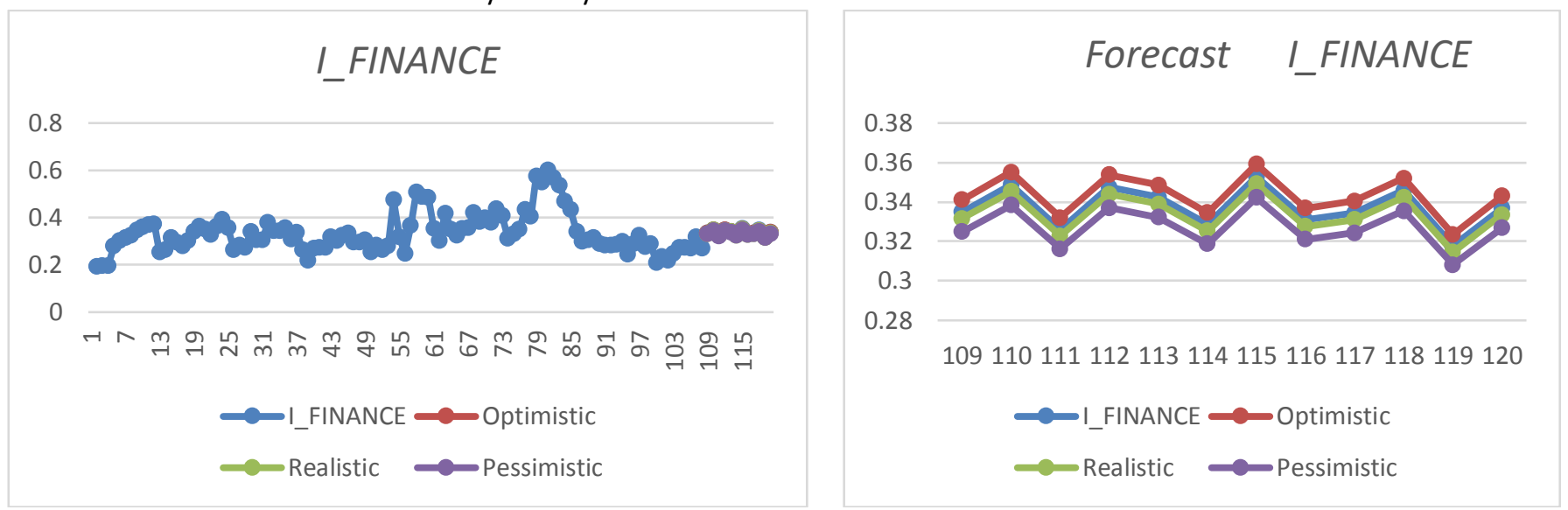

Forecast of the change in the integral index of financial sector (I_FINANCE) 


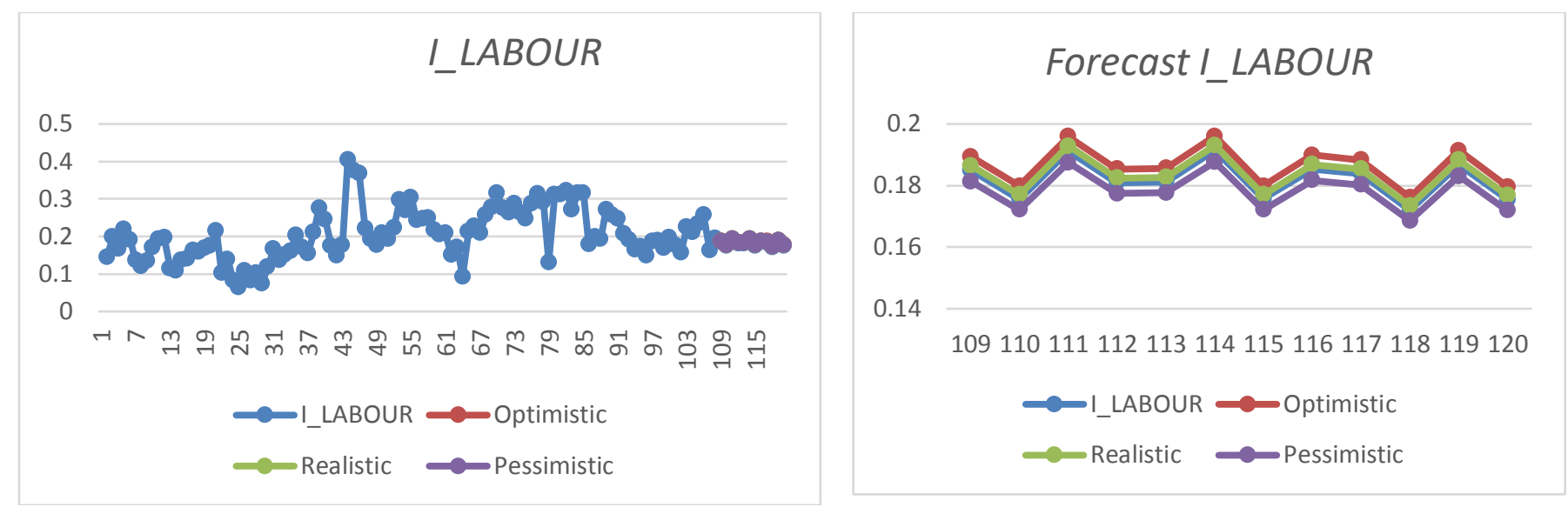

Forecast of the change in the integral index in human resourses (I_LABOUR)

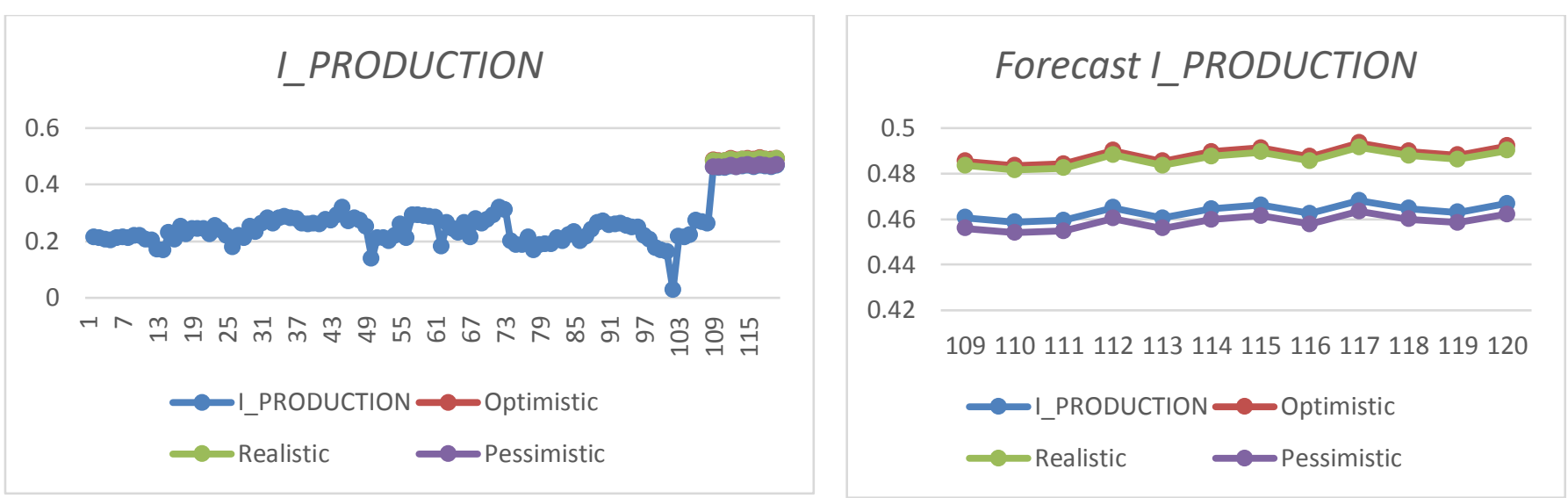

Forecast of the change in the integral index of industrial areas (I_PRODUCTION)
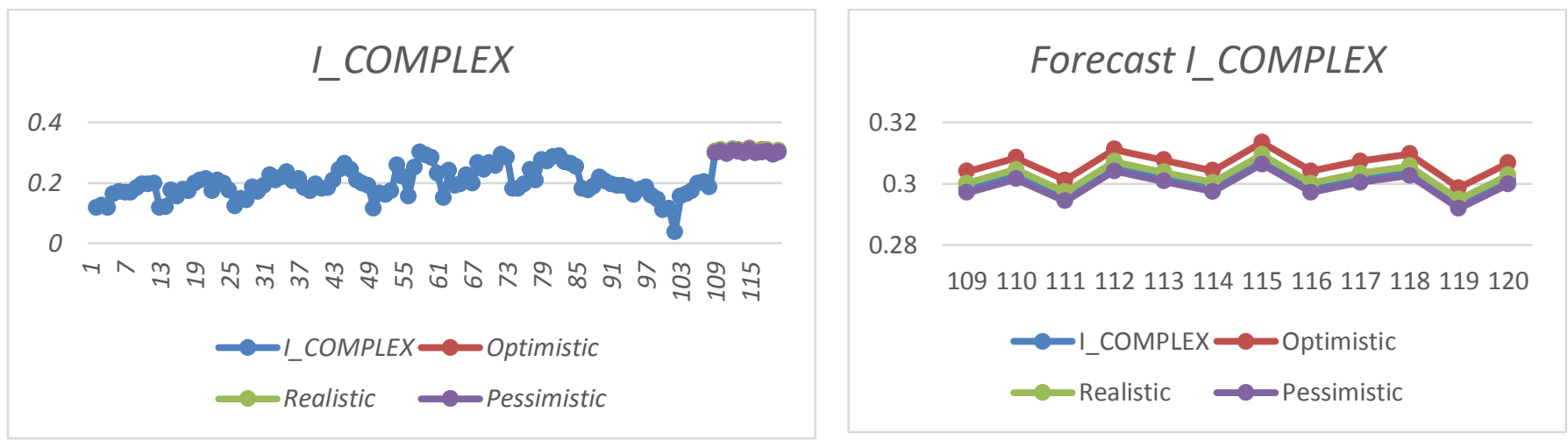

Forecast of changes in the general level of the complex integral index (I_COMPLEX)

Source: developed by the authors

The obtained forecasts of integral indicators of development level in the conditions of threats and the result of their implementation will allow us to predict possible scenarios of future situations and pre-implement local and general preventive measures taking into account the proposed management criteria.

\section{Conclusions}

1. The proposed complex of economic and mathematical models of evaluation and analysis of industrial systems strategic development is based on a single ideology analysis of the company on major spheres such as financial, production and labor, which form the strategic company resources. The feature and advantage of the developed 
complex of models is the usage of modern modeling tools of company strategic development, which is based on the concept of sustainability of the system and realization and implementation of which provides a selection of perspective alternatives to enterprise development in terms of threats, which makes possible to adapt to changes in the external and internal environment, taking into account the existing potential, adequate objectives, and development priorities, which will alleviate weaknesses in management.

2. As a result of building models for assessing and analyzing threats to enterprise external and internal environment, the main threats, that affect the enterprise development dynamics, their relevance, significance, interconnection are determined.

3. The constructed fuzzy inference rules allow us to make a more informed choice of possible development strategy in terms of threats according to changes in the values of integral indices of activity spheres is done. As the criterion for assessing advisability of company development scenarios we propose usage the maximum growing of integral complex indicator value of enterprise development level.

4. Scenario models based on the simulation mechanism that are implemented for industrial enterprises make possible to carry out multivariate calculations both at different levels of threats influence and their combination, and for development of adequate preventive actions, aimed at improving the management quality and improving the system efficiency in unstable environment and threats actions.

5. Realization of models of choice of the enterprise development possible alternatives on the basis of the rules of fuzzy conclusion allowed us to generate the possible scenarios of the enterprise development in the conditions of threats action and to predict the result of their realization that provides the choice of the best scenario from the considered criteria of significance.

6. After analyzing results of this criteria test under different scenarios we've determined that control management solution of enterprises development should be concentrated on the financial and production sector, adequate management of which reduce the risk of crisis factors impact.

7. The proposed set of models can also be used to enhance the validity of management decisions for enterprises of various industries and complexes strategic alternatives formation and realization in an unstable market environment, which improves the management quality level to maintain viability and promote activity adapted to each enterprise.

\section{Bibliographic references}

Andrew R. (2002). Webb Statistical Pattern Recognition. QinetiQ LTD, Malvern, UK. Retrieved from http://www.ccas.ru/voron/download/books/machlearn/webb02statistical.pdf

Andriushchenko, I. Ye. (2017). Formation of viability of industrial enterprises: monograph. State Higher Educational Institution of Azov State Technical University. Mariupol: PDTU.

Anisimova, L.A., Balan, V.G. (2011). Modeling the process of formation and selection of enterprise development strategies. Bulletin of the University of Kiev, 128, 24-27.

Ansof, H. I. (1970). Corporate Strategy. Penguin Books Ltd.

Dubois D. What Are Fuzzy Rules and How to Use Them Institut de Recherche en Informatique de Toulouse (I.R.I.T.) - C.N.R.S./ D. Dubois, H.

Prade. Retrieved from http://citeseerx.ist.psu.edu/viewdoc/downloaddoi=10.1.1.54.2479\&rep=rep1\&type $=p d f$ 
Duggan J. (2016). An Introduction to System Dynamics. System Dynamics Modeling with R. Cham: Springer International Publishing. doi 10.1007/978-3-319-34043-2_1.

Godun V.M., Orlenko N.S. \& Sendzyuk M.A. Information systems and technologies in statistics. Retrieved from http://library.if.ua/book/80/5668.html.

Guryanova L.S., Klebanova, T.S. \& Prokopovich, S.V. (2016). Applied econometrics. Part 1. Kharkiv: KhNEU named after S. Kuznets. Retrieved from http://repository.hneu.edu.ua/bitstream/123456789/19846/1/2016Гурьянова_л_С_Клебанова_Т_C_Прокопович_C_B.PDF

Guryanova L.S., Klebanova, T.S. \& Prokopovich, S.V. (2016). Applied econometrics. Part 2. Kharkov: KhNEU named after S. Kuznets. Retrieved from http://www.repository.hneu.edu.ua/bitstream/123456789/19842/1/2016Гур_янова_л_С_Клебанова_Т_С_та_ін.PDF

Handbook of econometrics (2007). Edited by J. J. Heckman, E.L. Amsterdam. North Holland/Elsevier.

lastremska O., Strokovych H., Dzenis O., Shestakova O. \& Uman T. (2019). Investment and innovative development of industrial enterprises as the basis for the technological singularity. Problems and Perspectives in Management, Vol. 17. Is. 3, 477-491.

Ivanov Y.B. \& Kapustnik S.K. (2015). Economic expertise of strategic decisions in the system of strategic management of enterprise development. Business Inform, 9, 409-414. Retrieved from https://www.business-inform.net/export_pdf/business-inform-2015-9_0-pages-409_414.pdf

Kaplan, R.S. \& Norton, D.R. (2000). The Strategy-Focused Organization: How Balanced Scorecard Companies Thrive in the New Business Environment. Harvard Business Review Press.

Klebanova T.S., Guryanov L.S. \& Chagovets L.O. (2018). Business analytics of multidimensional processes. Kharkov: KhNEU named after S. Kuznets. Retrieved from http://www.repository.hneu.edu.ua/bitstream/123456789/22020/1/2018Клебанова\%2СГурьянова\%2С\%20Чаговец\%20и\%20др.pdf

Leonenkov A. V. (2003). Fuzzy modeling in environment MATLAB i fuzzyTECH. SPb: BHV-Peterburg. Retrieved from http://www.bwbooks.net/index.php?id1=4\&category=comp-lit\&author=leolenkovav\&book=2005

Lepa R.N., Okhten A.A. \& Prokopenko R.V. (2016). Management of the development of industrial enterprises in the context of neo-industrialization: mechanism, models and methods: monograph. NAS of Ukraine, Institute of Industrial Economics. Kiev. Retrieved from https://iie.org.ua/wpcontent/uploads/monografiyi/2016/2016_mono_Lepa_Okhten_prokopenko2016.pdf

Lotfi A. Zadeh (2010). A Summary and Update of Fuzzy Logic. GRC'10 Proceedings of the 2010 IEEE International Conference on Granular Computing, 42-44. doi 10.1109/GrC.2010.144

Mintzberg G., Alstrand B., Lampel J. (2000) School of Strategy. St. Petersburg: Peter, 336.

Otenko I. \& Parkhomenko N. (2019). Strategies of Business Systems Development in Global Environment. Scientific Annals of Economics and Business, 66(2), 153-166. doi: http://dx.doi.org/10.2478/saeb-20190010

Pearce II, J.A. \& Robinson, R.A. (2010). Strategic Management. McGraw-Hill Education. 
Pluta, V. (1980). Comparative multidimensional analysis in economic research, Moscow, Statistics, 151.

Pogorelov Y.S. (2010). Assessment and modeling of enterprise development. monograph, Lugansk, 512.

Pollanen R., Abdel-Maksoud A., Elbanna S. \& Mahama H. (2016). Relationships between Strategic Performance Measures, Strategic Decision-making, and Organizational Performance: Empirical Evidence from Canadian Public Organizations. Public Manag. Rev, 19, 725-746.

Practical experience of information-analytical support of procedures of development and decision-making. Retrieved from http://www.ecsor.com.ua/files/conf_report_2_ukr.pdf.

Raevneva O.V. (2006). Enterprise development management: methodology, mechanisms, models: monograph. Kh.:VD INZHEK, 496.

Raudys S. (2001). Statistical and Neural Classifiers: An Integrated Approach to Design. Springer, London. doi: $10.1007 / \mathrm{s} 10044-003-0203-0$

Sergienko O., Shapran O., Bilotserkivskyi O. \& Alieksieieva I. (2019). Multi-scale model elaboration for creditworthiness diagnostics of export production enterprises of the agricultural trade market. EUREKA: SOCIAL AND HUMANITIES, 6, 19-30. Retrieved from http://eu-jr.eu/social/article/view/1082

Sergienko O.A., Tatar M.S. \& Golofaieva I.P. (2018). Analytical and applied aspects of modeling internal and external threats to enterprise financial security : monograf (396-413pp.). Information Economics: Stages of Development, Management Methods, Models (Edited by V.S. Ponomarenko, T.S. Klebanova). Kharkov, VSHEM - KHNEU. Retrieved from http://repository.kpi.kharkov.ua/bitstream/KhPIPress/39531/3/2018_Sergienko_Analytical_and_applied.pdf

Sergienko O.A., Tatar M.S., Chuiko I.M. \& Milevsky S.V. (2015). A multicomponent model of the generation of competitive strategies for the development of metallurgical enterprises: temporal, spatial and structural aspects. Applied aspects of modeling of socio-economic systems / Ed. Prof. V.S. Ponomarenko, Doctor of Economics, Prof. T. S. Klebanov. Berdyansk: Ed. Tkachuk.

Shershneva Z. E. \& Oborska S. V. (1999). Strategic management. K. : KNEU.

Shestakova, E.V. (2016). Self-organizing socio-economic systems: theory, methodology, mechanisms. M. : CREATIVE ECONOMY. doi: 10.18334/9785912921469

Smovzhenko, T. S. \& Azarenkova, G. M. (2014). Current status and problems of business development: monograph, Kiev: UBS NBU.

Soshnikova, L., Tamashevich, V. (1999). Multidimensional statistical analysis in the economy, Moscow, YUNITIDANA, $598 \mathrm{p}$.

Tatar M., Sergienko O., Kavun S. \& Guryanova L. (2017). Complex of management models of the enterprise competitiveness for steel industry in the currency instable environment. Economic Studies, Vol. 26, Is. 5, 102-124.

Tsopa, N.V. (2010). Industrial enterprise development management: methodology, models, methods: monogr. NAS of Ukraine, Donetsk-Simferopol, IT ARIAL, 320.

Torój A. Nonstationarity. Error Correction Models Econometric Methods (Warsaw School of Economics). Retrieved from http://web.sgh.waw.pl/ atoroj/econometric_methods/lecture_6_ecm.pdf 
Voronkova, A. E. (2004). Strategic management of competitive potential of the enterprise: diagnostics and organization: monograph. Lugansk: Publishing House of the East Ukrainian National University named after Vladimir Dahl.

Voronov A. A. \& Katichev V. F. (2004). Indicators and methods for assessing the effectiveness of the organizational and economic mechanism for managing an industrial enterprise. Management in Russia and abroad, 4, 98-108.

Wooldridge J. M. (2002). Econometric Analysis of Cross Section and Panel Data. MIT Press. Retrieved from https://jrvargas.files.wordpress.com/2011/01/wooldridge_j_2002_econometric_analysis_of_cross_sectio n_and_panel_data.pdf 